need for well-trained technologists, but also gave no indication of the Government's plans. Mr. David Cardwell, the acting principal, referred to the way in which uncertain financial backing had led to students having to abandon advanced courses before completion and urged the necessity of an extension of grants for postgraduate research. Mr. Cardwell also referred to the high quality of the part-time students and the potentialities of such students for increasing the supply of university graduates in science and technology. The City Council, he said, is pressing forward with a building programme for the. College which would cost some $£ 1,600,000$.

\section{International Nutrition Congress}

The second International Congress of Nutrition, held under the auspices of the International Union of Nutritional Sciences, has just concluded at Basle. At a meeting of the Executive Committee of the Union, attended by representatives from sixteen nations, it was unanimously decided to accept the invitation of the Netherlands members to hold the third International Congress in Amsterdam in tho summer of 1954. Prof. E. J. Bigwood (Brussels) was re-elected chairman of the Committee and Dr. Leslie J. Harris (Cambridge) honorary secretary. The following national, or organizational, representatives served on the Committee: Prof. E. J. Bigwood (Belgium), Dr. Morley Whillans (Canada), Prof. H. Dam (Denmark), Prof. A. I. Virtanen (Finland), Prof. E. Terroine (France), Prof. H. Kraut (Germany), Dr. M. Demarchi (Iraq), Dr. F. Mancini (Italy), Dr. A. Seliskar (Jugoslavia), Dr. M. van Eekelen and Prof. B. C. P. Jansen (Netherlands), Mrs. B. Q. Werenskiold (Norway), Prof. E. Abramson (Sweden), Prof. K. Bernhard and Prof. F. Verzár (Switzerland), Mr. A. L. Bacharach and Dr. L. J. Harris (United Kingdom), Dr. S. G. Greenberg (U.S.A.), Dr. W. K. Aykroyd (Food and Agriculture Organization), Dr. T. Norris (World Health Organization), Dr. D. P. Cuthbertson (Scottish Group, Nutrition Society), Miss D. F. Hollingsworth (International Dietetic Congress).

\section{Regeneration and Re-afforestation}

IN Forestry Abstracts, Vol. 12, No. 4 (Commonwealth Forestry Bureau, Oxford, June 1951), under "Sylviculture", F. C. Hummel describes "The Sylviculture of Mixtures in some Torests in S.W. Germany". The general policy, as contrasted with the almost universal habit in Germany during the past century and before of pure coniferous crops, is now to grow conifers and broad-leaved species in mixture. This involves what is almost a revolution in sylvicultural and managernent methods, and the possibilities of applying them under British conditions are described. In discussing the degree in which artificial assistance is given to this new regeneration, it is mentioned that beech and other broad-leaved species are often transplanted when $46 \mathrm{ft}$. high; but it is necessary to prune both the roots and crowns of such large plants and to stake them. The method is not new. In the old days, when the Forest of Dean was resown with acorns, the practice was to put in at every $20 \mathrm{ft}$. or so an oak transplant of 4-5 ft. in height. The method is employed by the French in the tropical rain-forest of the Ivory Coast in West Africa. In re-afforesting work, transplants $1_{2} \cdots 2 \mathrm{~m}$. in height are used. $P$. Dineur discusses the ecology of Quercus sessiliflora $(Q$. petroea) ; measurements of light under various degrees of canopy closure were undertaken for seedling regeneration, using a photometer of photoelectric cell type. Sylviculturists have for years advocated the possibility of being able to ascertain the more-or-less exact light requirements of seedlings under overhead canopy. It looks as if data on this problem may be obtainable. Lessons long since learnt in India are discussed by 'T. S. Serevo on "Silvicultural Observations in Cut-over Areas in Ajusan, Philippines". Logging was undertaken in an over-mature Dipterocarp forest with sparse advance growth. It is impossible to remove the main stand in such a type of forest without destroying all the undergrowth, since with the removal of the canopy the forest floor dries up. The dangers of logging in tropical forests are pointed out. The lesson was learnt in Madras in the years following the First World War, when attempts were made to introduce Canadian and American methods of logging into the evergreen forests. The result was a failure and a considerable pecuniary loss. But the lesson was learnt once and for all for India. The breaking of the overhead canopy exposes the moist soil below, never before exposed, to heat, heavy rain and wind, and it is quickly dissipated; the area is then useless for agriculture and difficult to re-afforest.

\section{National Foundation for Scientific Research, Brussels:} Annual Report for 1950-51

THE twenty-fourth annual report of the National Foundation for Scientific Research, Brussels (pp. 193 ; 1951 ), covering the year $1950-51$, refers to the establishment on July 26, 1951, of the Inter-University Institute of Nuclear Sciences and to the increase of its financial resources from 20 million to 25 million francs. The Atomic Energy Commission has also since established, on April 9 this year, a Centre of Studies for the Application of Nuclear Energy, which, mainly under academic direction, will be responsible for the utilization of the products of the Belgian nuclear reactor. A list of publications of the nuclear physics centres at Brussels and Louvain during 1947-51 is included; work at the Ghent centre has included technological research on the preparation of graphite and metallic uranium and on photographic emulsions, and at the Liège centre on absorbent media for gamma-rays and neutrons, the application of photographic emulsions, nuclear chemistry and the construction of a high-tension generator of the Panthenier type. During 1951-52 the Foundation has distributed sixty subsidies, totalling $3 \cdot 2$ million francs and including contributions towards the cost of construction of an electronic calculating machine, an oceanographic research station at La Rochelle-Pallice, an insectarium at Mentone, an epigraphic and archæological survey of the two provinces of Nejran and Hasa in SaudiArabia, the construction of a heliostat for the scientific station of the Jungfraujoch, for excavations at Alba Fucens, for studies on the performance of gas turbines, and for studies of tho radiation of the night sky at Arosa Observatory in co-operation with the HighAltitude Research Centre at Pasadena. Details of the distribution of radioisntopes in Belgium are included in the report, to which are appended lists of recipients of grants for 1951-52 and of papers by recipients of grants published during 1950-51.

\section{Human Relations in Industry}

THE report of the conference on human relations in industry, arranged by the Ministry of Labour and National Service during March 18-20 (see Nature, 169,$872 ; 1952$ ), has now been published (pp. 128; 